\title{
ANALISA FAKTOR-FAKTOR YANG MEMPENGARUHI KINERJA SUMBER DAYA MANUSIA DALAM PELAKSANAAN PEKERJAAN BEKISTING SEMI MODERN PADA KONSTRUKSI BANGUNAN GEDUNG
}

\author{
Analysis of Factors Affecting The Performance of Human Resources in The \\ Implementation of Semi-modern Formwork on Building Construction
}

\author{
Teguh Setiawan Suprabowo' ${ }^{1}, \quad$ M. Ruslin Anwar ${ }^{2}, \quad$ Indradi Wijatmiko ${ }^{3}$ \\ 1,2,3 Jurusan Teknik Sipil, Universitas Brawijaya Malang \\ Jl. MT. Haryono 167, Malang 65145, Indonesia \\ Alamat korespondensi: \\ Email: teguhs@gmail.com
}

\begin{abstract}
Semi-modern formwork is one of the work items that is almost always present in every implementation of building construction and has a great influence on success a project. The problems that arise in the implementation of the formwork is the workers who did not understand the employment implementation scope of semi-modern formwork, it certainly affects the declining performance of human resources so it can make a decline the quality of buildings, delays and additional cost of the project as well as allow the occurrence of failure structures that lead to the failure of a building construction project. This study aimed to analyze the factors affecting the performance of human resources in the implementation of semi-modern formwork on building construction which includes work ability factor, work discipline factor, a factor of wages, work environment, and work supervision factor. Analyses were performed using multiple linear regression methods and the method of analytical hierarchy process (AHP). Data were analyzed with multiple linear regression methods in this study is a questionnaire that distributed to 94 semi-modern formwork workers on the project of constructs buildings in the city of Surabaya. For analysis of AHP method, used five respondents who are skilled experts in semi-modern formwork. Based on the results of multiple linear regression analysis showed that the factors included in the study all of them affect the performance. Results of AHP analysis and multiple linear regression alike, shows that the dominant factor affecting the performance of human resources in the implementation of semimodern formwork on building construction is working ability factor.
\end{abstract}

Keywords : Semi-Modern Formwork, Performance, Multiple Linear Regression, Analytical Hierarchy Process

Abstrak
Bekisting semi modern merupakan salah satu item pekerjaan yang hampir selalu ada dalam
setiap pelaksanaan konstruksi bangunan gedung dan memiliki pengaruh yang besar terhadap
keberhasilan suatu proyek. Permasalahan yang muncul dalam pelaksanaan pekerjaan bekisting
yaitu para pekerja yang tidak begitu memahami tentang ruang lingkup dalam pelaksanaan
pekerjaaan bekisting semi modern, hal ini tentunya berpengaruh terhadap menurunnya kinerja
sumber daya manusia sehingga dapat menyebabkan menurunnya kualitas bangunan,
keterlambatan dan penambahan biaya proyek serta memungkinkan terjadinya kegagalan
struktur yang memicu terjadinya kegagalan dalam suatu proyek konstruksi
gedung. Penelitian ini bertujuan untuk menganalisa faktor-faktor yang mempengaruhi kinerja
sumber daya manusia dalam pelaksanaan pekerjaan bekisting semi modern pada konstruksi
bangunan gedung yang meliputi faktor kemampuan kerja, faktor disiplin kerja, faktor upah
kerja, faktor lingkungan kerja, dan faktor pengawasan kerja. Analisa dilakukan dengan
menggunakan metode regresi linear berganda dan metode analytical hierarchy
process (AHP). Data yang dianalisa dengan metode regresi linear berganda dalam penelitian
ini merupakan kuesioner yang disebarkan kepada 94 pekerja bekisting semi modern pada
proyek kostruksi bangunan gedung di kota Surabaya. Untuk analisa metode AHP, digunakan
lima responden yang merupakan pakar ahli dalam pekerjaan bekisting semi
modern. Berdasarkan hasil analisa regresi linear berganda menunjukan hasil bahwa faktor-
faktor yang dimasukkan dalam penelitian semuanya berpengaruh terhadap kinerja. Hasil
analisa metode AHP dan regresi linear berganda sama-sama menunjukkan hasil bahwa faktor


yang dominan mempengaruhi kinerja sumber daya manusia dalam pelaksanaan pekerjaan bekisting semi modern pada konstruksi bangunan gedung yaitu faktor kemampuan kerja.

Kata kunci : Bekisting Semi Modern, Kinerja, Regresi Linear Berganda, Analytical Hierarchy Process.

\section{PENDAHULUAN}

Dalam dunia konstruksi, formwork atau bekisting merupakan suatu item pekerjaan yang tak terlepas dalam suatu pekerjaan konstruksi bangunan, terutama untuk bangunan konstruksi gedung. Saat ini jenis dan metode-metode pelaksanaan terkait dengan pekerjaan bekisting terus dikembangkan sehingga mampu memberikan hasil yang lebih baik dalam suatu proyek konstruksi.

Seiring dengan kemajuan teknologi, bekisting jenis semi modern sering dipilih dalam pelaksanaan bangunan konstruksi terutama untuk proyek-proyek besar dan tipikal. Hal ini dikarenakan tipe bekisting semi modern merupakan bekisting yang peralatannya menggunakan gabungan antara kayu dan bahan fabrikasi. Adapun kelebihan dari jenis bekisting ini yaitu mampu menghemat biaya karena kayu bukan material utama dari bekisting ini namun kayu hanya digunakan pada bagian tertentu seperti bekisting kontak yang menggunakan bahan playwood, dalam pelaksanaannya pun memberikan hasil yang optimal dalam pekerjaan beton sehingga tidak hanya lebih cepat dari bekisting konvensional, tetapi juga hemat dalam segi anggaran.

Dalam pelaksanaan pekerjaan bekisting semi modern terkadang mengalami beberapa permasalahan yang terkait dengan kinerja sumber daya manusia yakni permasalahan pekerja yang kurang mengerti tentang keseluruhan metode pelaksanaan pekerjaan bekisting semi modern seperti penentu jenis tumpuan, keterkaitan dengan metode pelaksanaan kerja, serta pemahaman sederhana terkait dengan struktur kolom dan lainnya. Hal ini mempengaruhi hasil kinerja di dalam suatu proyek konstruksi, sehingga apabila hal-hal tersebut terjadi akan mengakibatkan menurunnya kualitas bangunan, keterlambatan proyek, penambahan biaya proyek dan bukan tidak mungkin menyebabkan suatu kegagalan dan kecelakaan yang terjadi dalam pelaksanaan suatu proyek konstruksi gedung. Oleh karena itu hasil dalam penelitian ini diharapkan mampu memberikan kontribusi terkait dengan faktor-faktor yang mempengaruhi kinerja pekerjaan bekisting semi modern pada suatu proyek konstruksi gedung sehingga nantinya dalam pelaksanaannya mampu memaksimalkan kinerja sumber daya manusia serta mendapatkan hasil yang optimal.

Tujuan dalam penelitian ini adalah sebagai berikut :

- Untuk mengetahui faktor-faktor apa sajakah yang dapat mempengaruhi kinerja sumber daya manusia dalam pelaksanaan pekerjaan bekisting semi modern pada pelaksanaan konstruksi bangunan gedung menurut para pekerja.

- Untuk mengetahui faktor yang mendominasi mempengaruhi kinerja sumber daya manusia dalam pelaksanaan pekerjaan bekisting semi modern pada pelaksanaan konstruksi bangunan gedung menurut para pekerja.

- Untuk mengetahui prioritas faktor-faktor yang dapat mempengaruhi kinerja sumber daya manusia dalam pelaksanaan pekerjaan bekisting semi modern pada pelaksanaan konstruksi bangunan gedung menurut pakar ahli.

Batasan dalam penelitian ini adalah sebagai berikut :

- Penelitian ini tidak melakukan pengamatan pada pelaksanaan pekerjaan bekisting semi modern sampai dengan hasil kinerja bekisting. Penelitian hanya dilakukan dengan wawancara dan pengisian kuesioner terhadap pekerja dan pakar ahli atau orang yang dianggap expert yang berkaitan dengan pekerjaan bekisting semi modern.

- Analisa yang dilakukan meliputi pakar ahli dan para pekerja konstruksi dengan item pekerjaan bekisting semi modern pada proyek konstruksi bangunan gedung di kota Surabaya.

- Penelitian ini menggunakan program SPSS untuk analisa regresi linear berganda yang bertujuan untuk mengetahui faktor-faktor yang 
berpengaruh terhadap kinerja dan pengujiannya.

- Analisa metode AHP dilakukan untuk mengetahui faktor prioritas terbaik yang mempengaruhi kinerja sumber daya manusia menurut pakar ahli.

\section{Kinerja}

Penilaian kinerja merupakan suatu cara untuk mengukur kinerja pekerja dalam sebuah perusahaan atau organisasi. Kesediaan dan keterampilan seseorang tidaklah cukup efektif untuk mengerjakan sesuatu tanpa pemahaman yang jelas tentang apa yang dikerjakan dan bagaimana mengerjakannya. Kinerja merupakan suatu perilaku nyata yang ditampilkan setiap orang atau pekerja sebagai prestasi kerja yang dihasilkan oleh pekerja sesuai dengan perannya dalam suatu perusahaan atau organisasi.

Menurut pendapat Robert L. Mathis dan John H. Jackson (2006, p382) penilaian kinerja (performance appraisal) adalah proses mengevaluasi seberapa baik karyawan melakukan pekerjaan mereka jika dibandingkan dengan seperangkat standar dan kemudian mengkomunikasikan informasi tersebut pada karyawan.

\section{Bekisting Semi Modern}

Menurut Wigbout (1997), bekisting semi modern merupakan bekisting yang materialnya terbuat dari gabungan kayu atau bambu dengan bahan fabrikasi.

Dalam pelaksanaan proyek sering terjadi kecelakaan kerja atau kegagalan struktur yang terjadi pada saat pelaksanaan pekerjaan beton berlangsung, hal ini banyak disebabkan akibat kesalahan bekisting yang biasanya terjadi pada saat pengecoran dimana beton basah masih menjadi beban sepenuhnya. Namun demikian pengalaman yang kuat dalam mendesain dan melaksanakan mampu meminimalisir kecelakaan kerja dapat terjadi.

$$
\text { Dalam pelaksanaan proyek }
$$

konstruksi bangunan gedung, untuk pelaksanaan pekerjaan bekisting semi modern dapat melalui berbagai tahapan yaitu meliputi :

- Fabrikasi bekisting

- Pemasangan bekisting

- Pembongkaran bekisting
Menurut Wigbout (1997), ada beberapa faktor yang menjadi pertimbangan untuk mengambil suatu keputusan mengenai pemilihan metode bekisting yang akan dipakai dalam suatu proyek konstruksi, yaitu:

- Kondisi struktur yang akan dikerjakan

- Luasan bangunan yang dipakai

- Ketersediaan material dan alat

\section{Regresi Linear Berganda}

Analisis regresi linier berganda adalah hubungan secara linear antara dua atau lebih variabel independen $\left(\mathrm{X}_{1}, \mathrm{X}_{2}, \ldots . \mathrm{X}_{\mathrm{n}}\right)$ dengan variabel dependen (Y). Persamaan regresi linear berganda sebagai berikut:

$$
Y^{\prime}=a+b_{1} X_{1}+b_{2} X_{2}+\ldots . .+b_{n} X_{n}
$$

Pada penelitian ini analisa regresi linear berganda dibantu dengan program SPSS (Statistical Package For Service Solution). Program SPSS adalah program pengolahan statistik yang paling umum digunakan dalam penelitian yang menggunakan data kuantitatif atau data kualitatif yang dikuantitatifkan.

Penggunaan program tersebut untuk analisa regresi dengan langkah meliputi : Analyse ..> regression ..> linear. Pada jeda yang ada, klik variabel terikat lalu klik tanda panah pada kotak dependen. Hal tersebut dilakukan dengan cara yang sama untuk variabel bebas (independent), lalu klik OK dan akan muncul output SPSS.

\section{Analytical Hierarchy Process (AHP)}

Analytical Hierarchy Process (AHP) merupakan salah satu teknik dalam pengambilan keputusan. AHP merupakan metode yang dikembangkan oleh Thomas L Saaty untuk mengatasi permasalahan dalam mengambil keputusan serta menentukan prioritas terbaik berdasarkan alternatifalternatif yang dibandingkan.

Dalam menganalisa metode AHP, langkah-langkah penyusunannya adalah sebagai berikut : (Saaty, T L, 1990)

- Mendefinisikan masalah dan menentukan solusi yang diinginkan.

- Membuat struktur hirarki yang diawali dengan tujuan umum, dilanjutkan dengan subtujuan-subtujuan, kriteria dan kemungkinan alternatif-alternatif pada tingkatan paling bawah. 
- Membuat matrik perbandingan berpasangan yang menggambarkan kontribusi relatif atau pengaruh setiap elemen terhadap masing-masing tujuan atau kriteria yang setingkat diatasnya.

- Melakukan perbandingan berpasangan sehingga diperoleh judgment seluruhnya sebanyaknya $\mathrm{n} \times$ [(n-1)/2] buah, dengan $n$ adalah banyaknya elemen yang dibandingkan.

- Menghitung nilai eigen vector dan menguji konsístensinya, jika tidak konsisten maka pengambilan data diulangi.

- Mengulangi langkah 3,4 dan 5 untuk seluruh tingkat hirarki.

- Menghitung eigen vector dari setiap matriks perbandingan berpasangan.

- Memeriksa konsistensi hirarki jika nilainya lebih dari $10 \%$ maka penilaian data judgment harus diperbaiki.

\section{Konsistensi Hirarki}

Pengukuran konsistensi dari suatu matriks itu sendiri didasarkan atas eigen value maksimum. Nilai eigen value maksimum diperoleh dari hasil perkalian antara jumlah matrik perbandingan berpasangan dengan nilai vektor eigen dan kemudian dijumlahkan untuk masing-masing ordo. Thomas L. Saaty telah membuktikan bahwa indeks konsistensi dari matriks berordo $\mathrm{n}$ dapat diperoleh dengan rumusrumus sebagai berikut :

$$
\begin{aligned}
& \mathrm{CI}=(\lambda \max -\mathrm{n}) /(\mathrm{n}-1) \\
& \mathrm{CR}=\mathrm{CI} / \mathrm{RI}
\end{aligned}
$$

Keterangan :

$$
\begin{array}{ll}
\mathrm{CI} & : \text { Consistency indeks } \\
\lambda \mathrm{max} & : \text { Nilai eigen terbesar } \\
\mathrm{CR} & : \text { Consistency Ratio } \\
\mathrm{N} & : \text { Ordo matriks } \\
\mathrm{RI} & : \text { Random Consistency Index }
\end{array}
$$

\section{METODE PENELITIAN}

\section{Konsep Penelitian}

Konsep penelitian ini dimulai dengan perumusan faktor-faktor yang mempengaruhi kinerja sumber daya manusia pada pelaksanaan pekerjaan bekisting semi modern yang meliputi kemampuan kerja, disiplin kerja, upah kerja, lingkungan kerja dan pengawasan kerja. Setelah perumusan faktor-faktor yang mempengaruhi kinerja dilanjutkan dengan analisa regresi linear berganda dan analisa metode AHP.

Analisa regresi linear berganda dilakukan untuk menguji variabel-variabel manakah yang mempengaruhi kinerja sumber daya manusia dalam pelaksanaan pekerjaan bekisting semi modern pada konstruksi bangunan gedung berdasarkan data kuesioner dari para pekerja dan mandor. Penggunaan analisa metode AHP digunakan untuk melihat faktor-faktor manakah yang mempengaruhi kinerja sumber daya manusia pada pelaksanaan pekerjaan bekisting semi modern pada konstruksi gedung berdasarkan penilaian pakar ahli.

\section{Populasi Dan Sampel Penelitian}

Populasi dalam penelitian ini adalah para pekerja bekisitng semi modern yang bekerja pada pelaksanaan konstruksi bangunan gedung di tiga proyek yang berlokasi dikota Surabaya. Ketiga proyek tersebut meliputi pembangunan proyek Hotel Arya Central Surabaya dengan perusahaan PT Bintang Anugerah Persada, proyek pembangunan Apartement The Samator dengan perusahaan PT Pembangunan Perumahan (persero) tbk, dan pembangunan proyek Apartement One East Residence dengan perusahaan PT Tata Mulia Indah.

Penentuan sampel dalam penelitian ini menggunakan metode purposive sampling. Dimana pemilihan responden dipilih secara sengaja oleh peneliti, hal ini dikarenakan data diambil dari pakar ahli atau orang yang dianggap expert serta berpengalaman dalam pekerjaan bekisting semi modern untuk analisa metode AHP, serta untuk analisa regresi linear berganda dipilih para pekerja proyek konstruksi yang bekerja dalam ruang lingkup pekerjaan bekisting semi modern pada proyek konstruksi bangunan gedung. Sampel dalam penelitian ini untuk analisa metode regresi linear berganda sejumlah 94 pekerja dan untuk metode AHP sejumlah 5 pakar bekisting semi modern.

\section{Teknik Pengumpulan Data}

Teknik pengumpulan data dalam penelitian ini menggunakan data primer dan data sekunder. Data primer diperoleh dari hasil wawancara untuk mencari informasi dan juga keterangan yang dibutuhkan dalam 
proses penelitian. Selaian itu, Data primer dalam penelitian ini berupa daftar pertanyaan yang telah disiapkan kepada responden yang berupa kueisoner. Penggunaan kuesioner tersebut merupakan teknik pengumpulan data dengan memberikan daftar pertanyaan kepada responden untuk memberikan informasi yang relevan dengan tujuan penelitian.

\section{Devinisi Operasional Variabel}

Devinisi operasional variabel dalam penelitian ini merupakan unsur penelitian yang menggambarkan pengukuran suatu variabel yang berisikan indikator yang memungkinkan peneliti mengumpulkan data yang relevan dalam penelitian tersebut. Adapun variabel dalam penelitian ini adalah sebagai berikut :

- Faktor kemampuan kerja (X1)

$\begin{array}{llr}\text { Kemampuan } & \text { kerja } & \text { merupakan } \\ \text { keberhasilan } & \text { seseorang } & \text { dalam }\end{array}$ melaksanakan tugas dan tanggung jawab dalam pekerjaanya. Indikator untuk mengukur kemampuan kerja meliputi :

- Kemampuan pekerja mengerjakan pekerjaan bekisitng sesuai dengan gambar kerja.

- Kemampuan pekerja memahami metode pelaksanaan kerja dalam pekerjaan bekisting

- Kemampuan pekerja dalam mengoperasikan peralatan kerja dalam pekerjaan bekisting.

- $\quad$ Faktor disiplin kerja (X2)

Disiplin kerja merupakan suatu sikap dan kerelaan pekerja dalam mematuhi dan menaati peraturan-peraturan dalam suatu perusahaan. Indikator untuk mengukur faktor disiplin kerja meliputi :

- Pekerja datang dan pulang tepat waktu.

- Pekerja memakai perlengkapan kerja.

- Pekerja menaati peraturan perusahaan.

- $\quad$ Faktor Upah Kerja (X3)

Upah kerja adalah balas jasa yang berupa uang atau balas jasa lain yang diberikan lembaga atau organisasi perusahaan kepada pekerjanya.

Indikator untuk mengukur faktor upah kerja meliputi :
- Penerimaan upah pekerja tetap waktu.

- Kesesuaian upah dengan masa kerja

- Upah pekerja memenuhi kebutuhan sehari-hari

- Faktor lingkungan kerja (X4)

Lingkungan kerja adalah segala sesuatu yang berada di sekitar para pekerja dan yang dapat mempengaruhi dirinya dalam menjalankan tugas-tugas yang diembankan kepada pekerja. Indikator untuk mengukur faktor upah kerja meliputi :

- Hubungan yang baik antara para pekerja satu dengan yang lainnya.

- Hubungan yang baik antara para pekerja dengan atasan.

- Peralatan keamanan memenuhi standart.

- $\quad$ Faktor pengawasan kerja (X5)

Pengawasan kerja adalah pengawasan yang dilakukan mandor terhadap pekerja dalam menyelesaikan pekerjaan. Pengawasan kerja juga merupakan wujud dari gaya kepemimpinan seorang atasan. Indikator untuk mengukur faktor pengawasan kerja meliputi :

- Mandor memberikan perintah dengan baik terhadap pekerja.

- Mandor menegakkan disiplin kepada pekerja dengan baik.

- Mandor menegur kesalahan pekerja dengan baik.

- $\operatorname{Kinerja(Y)}$

Kinerja merupakan suatu keberhasilan atau prestasi kerja yang diraih para pekerja dalam melaksanakan suatu pekerjaan. Indikator untuk mengukur kinerja meliputi :

- Pekerja melaksanakan pekerjaan bekisting sesuai pengawasan mandor.

- Pekerja menyelesaikan pekerjaan tetap waktu.

- Pekerja memiliki tanggung jawab dalam pelaksanaan pekerjaan bekisting. 


\section{HASIL DAN PEMBAHASAN}

\section{Analisa Regresi Linear Berganda}

Berdasarkan hasil analisa regresi linear berganda dengan menggunakan bantuan program Statistical Package For Service Solution (SPSS), maka didapatkan hasil rekapitulasi analisa yaitu sebagai berikut :

Tabel 1. Rekapitulasi hasil analisa regresi linear berganda

\begin{tabular}{ccccc}
\hline Variabel & B & thitung & Sig & Ket \\
\hline Nilai Konstanta & 2,272 & 3,933 & 0,000 & Sig \\
Kemampuan Kerja & 0,291 & 6,448 & 0,000 & Sig \\
Disiplin Kerja & 0,087 & 2,067 & 0,042 & $\mathrm{Sig}$ \\
Upah Kerja & 0,123 & 2,781 & 0,007 & $\mathrm{Sig}$ \\
Lingkungan Kerja & 0,131 & 3,199 & 0,002 & $\mathrm{Sig}$ \\
Pengawasan & 0,211 & 5,188 & 0,000 & $\mathrm{Sig}$ \\
\hline$\alpha$ & $=5 \%$ & & & \\
R Square & $=0,750$ & & & \\
F hitung & $=52,784$ & & & \\
Signifikan & $=0,000$ & & & \\
F tabel & $=2,31$ & & & \\
T tabel & $=1,985$ & &
\end{tabular}

Sumber : Analisa Data primer (2015)

Berdasarkan pada tabel 1, model regresi tersebut memiliki nilai $\mathrm{R}$ square sebesar 0,750, hal ini menunjukkan jika variabel X1-X5 secara bersama-sama mempengaruhi $\mathrm{Y}$ (Kinerja) sebesar 75,0\% dan sisanya $25,0 \%$ dipengaruhi oleh variabel lainnya yang tidak diteliti dalam penelitian ini.

Berdasarkan hasil penelitian didapatkan suatu model persamaan yaitu sebagai berikut :

$$
\begin{aligned}
\mathrm{Y}= & 2,272+0,291 \mathrm{X} 1+0,087 \mathrm{X} 2+0,123 \\
& \mathrm{X} 3+0,131 \mathrm{X} 4+0,211 \mathrm{X} 5
\end{aligned}
$$

Besarnya nilai konstanta sebesar 2,272 dan pengaruhnya ke arah positif. Hal ini mempunyai makna bahwa apabila variabel kemampuan kerja, disiplin kerja, upah kerja, lingkungan kerja, dan pengawasan kerja sama dengan nol, maka besarnya kinerja pelaksanaan pekerjaan bekisting sebesar 2,272.

Berdasarkan hasil persamaan tersebut juga dijelaskan kemampuan kerja merupakan faktor yang dominan dikarenakan mempunyai nilai koefisien $\mathrm{B}$ terbesar yaitu sebesar 0,291.

\section{Pengujian Hipotesis}

Pengujian secara simultan dilakukan untuk menunjukkan apakah semua variabelvariabel yang digunakan dalam model regresi memiliki pengaruh yang signifikan terhadap $\mathrm{Y}$. Dari hasil analisa menunjukkan bahwa $\mathrm{F}$ hitung $(52,784)>F$ tabel $(2,31)$. Selain itu juga didapatkan nilai signifikan sebesar 0,000 , jika nilai signifikan dibandingkan dengan koefisien alpha 5\% maka signifikan lebih kecil dari 5\%, sehingga dapat disimpulkan bahwa terdapat pengaruh secara simultan antara variabel X1-X5 terhadap Y atau keputusan tolak Ho.

Selain pengujian secara simultan, dilakukan pengujian secara parsial untuk mengetahui apakah masing-masing variabel independen secara individu memiliki pengaruh yang signifikan terhadap kinerja atau tidak. Pengujian secara simultan untuk masing-masing variabel dijelaskan sebagai berikut :

- Kemampuan kerja

Hasil penelitian menunjukan untuk variabel kemampuan kerja menunjukan bahwa nilai sig $=0,000$ lebih kecil dari nilai probabilitas 0,05 atau $0,000<$ 0,05, maka Ho ditolak dan Ha diterima, selain itu juga diperkuat dengan $\mathrm{t}$ hitung yang lebih besar dari t tabel atau 6,448 > 1,985. Jadi dapat disimpulkan kemampuan kerja memiliki pengaruh yang signifikan terhadap kinerja.

- Disiplin Kerja

Hasil penelitian untuk variabel disiplin kerja menunjukan bahwa nilai sig $=$ 0,042 lebih kecil dari nilai probabilitas 0,05 atau $0,042<0,05$, maka Ho ditolak dan $\mathrm{Ha}$ diterima, selain itu juga diperkuat dengan $\mathrm{t}$ hitung yang lebih besar dari $t$ tabel atau 2,067>1,985. Jadi dapat disimpulkan disiplin kerja memiliki pengaruh yang signifikan terhadap kinerja.

- Upah kerja

Hasil penelitian untuk variabel upah kerja menunjukan bahwa nilai sig $=$ 0,007 lebih kecil dari nilai probabilitas 0,05 atau $0,007<0,05$, maka Ho ditolak dan $\mathrm{Ha}$ diterima, selain itu juga diperkuat dengan $\mathrm{t}$ hitung yang lebih besar dari $t$ tabel atau 2,781 >1,985. 
Jadi dapat disimpulkan upah kerja memiliki pengaruh yang signifikan terhadap kinerja.

- Lingkungan kerja

Hasil penelitian untuk variabel lingkungan kerja menunjukkan bahwa nilai sig $=0,002$ lebih kecil dari nilai probabilitas 0,05 atau $0,002<0,05$, maka Ho ditolak dan Ha diterima, selain itu juga diperkuat dengan $\mathrm{t}$ hitung yang lebih besar dari t tabel atau 3,199 > 1,985. Jadi dapat disimpulkan lingkungan kerja memiliki pengaruh yang signifikan terhadap kinerja.

- Pengawasan kerja

Hasil penelitian untuk variabel pengawasan kerja menunjukkan bahwa nilai sig $=0,000$ lebih kecil dari nilai probabilitas 0,05 atau $0,000<0,05$, maka Ho ditolak dan Ha diterima, selain itu juga diperkuat dengan $t$ hitung yang lebih besar dari t tabel atau 5,188 > 1,985. Jadi dapat disimpulkan pengawasan memiliki pengaruh yang signifikan terhadap kinerja.

\section{Analytical Hierarchy Process (AHP)}

Proses analisa metode AHP pada penelitian ini dijelaskan pada gambar struktur hirarki yang dimulai dari tujuan, level kriteria sampai dengan level alternatif sebagai berikut

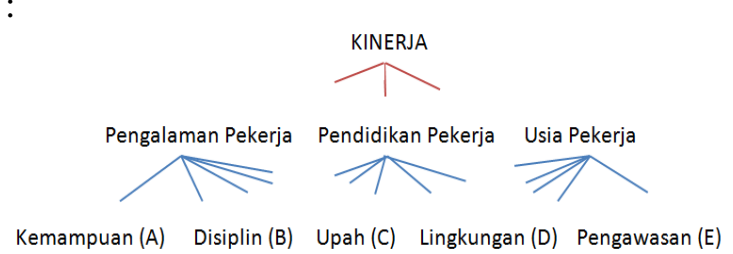

Gambar 1 : Bagan Struktur Hirarki

Pada gambar di atas dijelaskan struktur hirarki yang diawali dengan tujuan, kriteria dan alternatif. Pada level kriteria pada penelitian ini dibagi menjadi tiga kriteria meliputi pengalaman pekerja, pendidikan pekerja dan usia pekerja. Untuk level alternatif dimasukkan faktor-faktor yang mempengaruhi kinerja yang meliputi kemampuan, disiplin, upah, lingkungan, dan pengawasan. Nantinya hasil dalam penelitian ini akan diputuskan alternatif manakah yang dominan mempengaruhi kinerja berdasarkan karakteristik dalam struktur hirarki tersebut.

\section{Matrik Perbandingan Berpasangan Dan Pengujian Konsistensi Hirarki}

\section{Analisa Level Kriteria}

Analisa pada level kriteria akan membandingkan dari ketiga kriteria yaitu pengalaman pekerja, pendidikan pekerja dan usia pekerja. Dari hasil analisa level kriteria akan dihasilkan nilai dari masing-masing kriteria berupa nilai vektor eigen. Hasil analisa metode AHP level kriteria dijelaskan pada tabel matriks sebagai berikut :

Tabel 2. Matriks pair-wise level kriteria dan nilai eigen

\begin{tabular}{lcccc}
\hline Kriteria & $\begin{array}{c}\text { Pengalama } \\
\mathrm{n}\end{array}$ & Pendidikan & Usia & $\begin{array}{c}\text { Vektor } \\
\text { Eigen }\end{array}$ \\
\hline $\begin{array}{l}\text { Pengalama } \\
\mathrm{n}\end{array}$ & 1 & 1 & 2 & 0,411 \\
Pendidikan & 1 & 1 & 1 & 0,328 \\
Usia & 0,5 & 1 & 1 & 0,261 \\
\hline Jumlah & 2,50 & 3,00 & 4,00 & \\
\hline
\end{tabular}

Berdasarkan tabel di atas dapat dijelaskan bahwa kriteria pengalaman pekerja memiliki nilai yang terbesar yaitu 0,411 artinya pengalaman kerja adalah kriteria yang menjadi prioritas terhadap kinerja.

\section{Pemilihan Alternatif Untuk Kriteria Pengalaman Pekerja}

Pada level alternatif untuk kriteria pengalaman pekerja nantinya akan dibandingkan dengan faktor-faktor yang dimasukkan sebagai alternatif. Adapun analisa tersebut dijelaskan pada tabel matriks sebagai berikut :

Tabel 3. Matriks pair-wise alternatif untuk kriteria pengalaman pekerja

\begin{tabular}{cccccc}
\hline Alternatif & A & B & C & D & E \\
\hline A & 1 & 5 & 5 & 0,33 & 1 \\
B & 0,20 & 1 & 3 & 0,20 & 0,33 \\
C & 0,20 & 0,33 & 1 & 0,14 & 0,33 \\
D & 3 & 5 & 7 & 1 & 1 \\
E & 1 & 3 & 3 & 1 & 1 \\
\hline Jumlah & 5,40 & 14,33 & 19,00 & 2,68 & 3,67 \\
\hline
\end{tabular}


Tabel 4. Nilai eigen

\begin{tabular}{ccc}
\hline Alternatif & Vektor Eigen & Rangking \\
\hline Kemampuan & 0,239 & 3 \\
Disiplin & 0,086 & 4 \\
Upah & 0,051 & 5 \\
Lingkungan & 0,384 & 1 \\
Pengawasan & 0,240 & 2 \\
\hline
\end{tabular}

Berdasarkan tabel di atas dapat dijelaskan bahwa faktor lingkungan kerja memiliki nilai yang terbesar yaitu 0,384 artinya faktor lingkungan kerja lebih dipengaruhi oleh kriteria pengalaman pekerja. Faktor lingkungan kerja pada analisa tersebut menempati peringkat pertama sebagai faktor prioritas.

\section{Pemilihan Alternatif Untuk Kriteria Pendidikan Pekerja}

Pada level alternatif untuk kriteria pendidikan pekerja nantinya akan dibandingkan dengan faktor-faktor yang dimasukan sebagai alternatif. Analisa pemilihan alternatif untuk kriteria pendidikan pekerja tersebut akan dijelaskan pada tabel matriks sebagai berikut :

Tabel 5. Matriks pair-wise alternatif untuk kriteria pendidikan pekerja

\begin{tabular}{cccccc}
\hline Alternatif & A & B & C & D & E \\
\hline A & 1 & 3 & 1 & 1 & 3 \\
B & 0,33 & 1 & 0,20 & 1 & 0,50 \\
C & 1 & 5 & 1 & 3 & 1 \\
D & 1 & 1 & 0,33 & 1 & 1 \\
E & 0,33 & 2 & 1 & 1 & 1 \\
\hline Jumlah & 3,67 & 12,00 & 3,53 & 7,00 & 6,50 \\
\hline
\end{tabular}

Tabel 6. Nilai eigen

\begin{tabular}{ccc}
\hline Alternatif & Vektor Eigen & Rangking \\
\hline Kemampuan & 0,282 & 2 \\
Disiplin & 0,090 & 5 \\
Upah & 0,311 & 1 \\
Lingkungan & 0,149 & 4 \\
Pengawasan & 0,167 & 3 \\
\hline
\end{tabular}

Berdasarkan tabel di atas dapat dijelaskan bahwa faktor upah kerja memiliki nilai yang terbesar yaitu 0,311 artinya faktor upah kerja lebih dipengaruhi oleh kriteria pendidikan pekerja. Faktor upah kerja pada analisa tersebut menempati peringkat pertama sebagai faktor prioritas.

\section{Pemilihan Alternatif Untuk Kriteria Usia Pekerja}

Pada level alternatif untuk kriteria usia pekerja nantinya akan dibandingkan dengan faktor-faktor yang dimasukkan sebagai alternatif. Adapun analisa pemilihan alternatif untuk kriteria usia pekerja dijelaskan pada tabel matriks sebagai berikut

Tabel 7. Matriks pair-wise alternatif untuk kriteria usia pekerja

\begin{tabular}{cccccc}
\hline Alternatif & A & B & C & D & E \\
\hline A & 1 & 3 & 3 & 1 & 0,33 \\
B & 0,33 & 1 & 3 & 1 & 0,33 \\
C & 0,33 & 0,33 & 1 & 0,33 & 0,20 \\
D & 1 & 1 & 3 & 1 & 0,33 \\
E & 3 & 3 & 5 & 3 & 1 \\
\hline Jumlah & 5,67 & 8,33 & 15,00 & 6,33 & 2,20 \\
\hline
\end{tabular}

Tabel 8. Nilai Eigen

\begin{tabular}{ccc}
\hline Alternatif & Vektor Eigen & Rangking \\
\hline Kemampuan & 0,209 & 2 \\
Disiplin & 0,138 & 4 \\
Upah & 0,062 & 5 \\
Lingkungan & 0,161 & 3 \\
Pengawasan & 0,430 & 1 \\
\hline
\end{tabular}

Berdasarkan tabel di atas dapat dijelaskan bahwa faktor pengawasan kerja memiliki nilai yang terbesar yaitu 0,430 artinya faktor kemampuan kerja lebih dipengaruhi oleh kriteria usia pekerja. Faktor pengawasan kerja pada analisa tersebut menempati peringkat pertama sebagai faktor prioritas

\section{Konsistensi Hirarki}

Dalam analisa metode AHP, pengujian konsistensi dibutuhkan untuk melihat apakah data yang kita gunakan dalam penelitian telah konsisten atau tidak. Konsistensi hirarki dilihat berdasarkan nilai Consistency Ratio (CR) yang tidak melebihi $10 \%$. Hasil pengujian konsistensi tersebut disajikan pada tabel sebagai berikut 
Tabel 9. Konsistensi Hirarki

\begin{tabular}{l|cccc}
\hline \multicolumn{1}{c|}{ Level AHP } & $\lambda \max$ & CI & CR & CR $<10 \%$ \\
\hline Kriteria & 3,056 & 0,028 & 0,048 & Konsisten \\
Level Alternatif & & & & \\
Pengalaman & 5,407 & 0,102 & 0,091 & Konsisten \\
Pendidikan & 5,349 & 0,087 & 0,078 & Konsisten \\
$\quad$ Usia & 5,227 & 0,057 & 0,051 & Konsisten \\
\hline
\end{tabular}

Berdasarkan tabel di atas, dijelaskan nilai CR dari level kriteria sampai dengan level alternatif memiliki nilai lebih kecil dari $10 \%$ atau 0,1 . Hasil ini menunjukan bahwa analisa terhadap satu responden telah konsisten dan dapat dilanjutkan.

\section{Analisa Hasil Satu Responden}

Pada analisa akhir metode AHP untuk menentukan alternatif terbaik, akan dilakukan pengalian antara bobot kriteria dengan bobot alternatif. Hasil perkalian alternatif dengan nilai yang terbesar merupakan keputusan dalam penggunaan metode AHP berdasarkan salah satu pakar ahli yang dianalisa.

Adapun hasil analisa tersebut dijelaskan pada tabel 10 sebagai berikut :

Tabel 10. Matrik Analisa Keseluruhan

\begin{tabular}{ll|lrrrr}
\hline & Weight & A & B & C & D & E \\
\hline Pengalaman & 0,411 & 0,239 & 0,086 & 0,051 & 0,384 & 0,240 \\
Pendidikan & 0,328 & 0,282 & 0,090 & 0,311 & 0,144 & 0,167 \\
Usia & 0,261 & 0,209 & 0,138 & 0,062 & 0,161 & 0,430 \\
\hline Composite & Weight & 0,245 & 0,101 & 0,139 & 0,249 & $\mathbf{0 , 2 6 6}$ \\
\hline Rangking & & 3 & 5 & 4 & 2 & 1 \\
\hline
\end{tabular}

Berdasarkan tabel matrik di atas, nilai faktor pengawasan kerja (E) adalah yang terbesar yaitu 0,266. Hasil ini menunjukan bahwa faktor yang berpengaruh terhadap kinerja sumber daya manusia dalam pelaksanaan pekerjaan bekisting semi modern pada konstruksi bangunan gedung menurut salah satu pakar ahli ialah faktor pengawasan kerja.

Untuk analisa keseluruhan sejumlah 5 responden pakar ahli, analisa dilakukan dengan langkah-langkah seperti yang telah dijelaskan pada analisa satu responden dengan cara yang sama untuk masing-masing responden. Nantinya akan direkapitulasi hasil untuk setiap analisa untuk masing-masing responden dan akan ditentukan nilai reratanya sebagai alternatif terbaik.

\section{Rerata Analisa Hasil Keseluruan Responden}

Setelah hasil analisa dilakukan untuk setiap responden, maka selanjutnya untuk memutuskan alternatif terbaik yaitu dengan cara melakukan rata-rata untuk setiap hasil analisa tersebut. Nilai rerata terbesar merupakan alternatif terbaik atau faktor yang dominan mempengaruhi kinerja. Adapun hasil rerata tersebut dijelaskan pada tabel sebagai berikut :

Tabel 11. Nilai Eigen

\begin{tabular}{cccccc}
\hline Responden & A & B & C & D & E \\
\hline 1 & 0,245 & 0,101 & 0,139 & 0,249 & 0,266 \\
2 & 0,240 & 0,180 & 0,163 & 0,114 & 0,303 \\
3 & 0,182 & 0,199 & 0,110 & 0,266 & 0,243 \\
4 & 0,308 & 0,086 & 0,161 & 0,249 & 0,194 \\
5 & 0,252 & 0,209 & 0,133 & 0,220 & 0,186 \\
\hline Rerata & $\mathbf{0 , 2 4 5}$ & 0,155 & 0,141 & 0,220 & 0,238 \\
\hline Rangking & 1 & 4 & 5 & 3 & 2 \\
\hline
\end{tabular}

Berdasarkan tabel nilai eigen di atas dijelaskan bahwa alternatif kemampuan kerja (A) merupakan alternatif dengan nilai ratarata terbesar yaitu 0,245. Hal ini dapat dijelaskan bahwa kemampuan kerja merupakan faktor dominan yang paling mempengaruhi kinerja pekerjaan bekisting semi modern menurut pakar ahli.

\section{Pembahasan}

Berdasarkan hasil analisa metode regresi linear berganda dan metode AHP, maka berikut akan dijelaskan urutan hasil dari kedua metode tersebut.

Tabel 12. Urutan Hasil Analisa Metode Regresi dan Metode AHP

\begin{tabular}{cll}
\hline No & Analisa Regresi Berganda & \multicolumn{1}{c}{ Analisa AHP } \\
\hline 1. & Kemampuan Kerja $(0,291)$ & Kemampuan Kerja $(0,245)$ \\
2. & Pengawasan Kerja $(0,211)$ & Pengawasan Kerja $(0,238)$ \\
3. & Lingkungan Kerja $(0,131)$ & Lingkungan Kerja $(0,220)$ \\
4. & Upah Kerja $(0,123)$ & Disiplin Kerja $(0,155)$ \\
5. & Disiplin Kerja $(0,087)$ & Upah Kerja $(0,141)$ \\
\hline
\end{tabular}


Berdasarkan hasil penelitian kedua metode tersebut, maka berikut akan dibahas pembahasan untuk masing-masing faktor yang mempengaruhi kinerja dalam penelitian tersebut.

\section{- Kemampuan Kerja}

Berdasarkan hasil penelitian yang telah dilakukan menurut pakar ahli dan pekerja bekisting menunjukan bahwa faktor kemampuan kerja merupakan faktor yang paling dominan mempengaruhi kinerja dibandingkan faktor-faktor yang lain. Dikarenakan faktor kemampuan kerja merupakan faktor yang dominan mempengaruhi kinerja, maka dalam pelaksanaan pekerjaan bekisting beberapa hal yang perlu diperhatikan terkait bagaimana cara memaksimalkan kemampuan kerja, terutama dalam metode pelaksanaan pekerjaan yang dimulai dari tahap perakitan bekisting, pemasangan sampai pengecoran beton dan pembongkaran bekisting. Setiap pekerja bekisting tentunya harus benar-benar memahami tentang teknik pelaksanaan pekerjaan dikarenakan dalam pekerjaan bekisting pada proyek konstruksi memiliki resiko yang besar apabila terjadi kesalahan dalam pelaksanaan pekerjaan.

Untuk mampu meningkatkan kemampuan para pekerja, perusahaan dirasa perlu melakukan kegiatan pelatihan kerja khususnya bagi para pekerja yang belum berpengalaman, hal ini dimaksudkan untuk meningkatkan kepahaman pekerja terhadap ruang lingkup pekerjaan bekisting pada proyek konstruksi gedung.

- Pengawasan Kerja

Pengawasan kerja merupakan kegiatan pengawasan yang dilakukan oleh mandor dalam pelaksanaan pekerjaan bekisting terhadap para pekerja.

Untuk mampu memaksimalkan pengawasan yang baik oleh para mandor terhadap pekerja dibutuhkan kemampuan kepemimpinan dari para mandor itu sendiri. Kemampuan memberikan arahan serta bimbingan dalam pelaksanaan pekerjaan yang baik akan sangat berpengaruh terhadap kemampuan pekerjanya. Namun dengan berbedabedanya karakteristik pekerja hal tersebut menjadi tantangan terbesar dari setiap mandor dalam memahami dan memberikan arahan kepada setiap pekerja.

- Lingkungan Kerja

Lingkungan kerja merupakan segala sesuatu yang berada dalam lingkungan para pekerja dan yang dapat mempengaruhi dirinya dalam bekerja. Lingkungan kerja yang baik ialah dimana para pekerja merasa aman dan nyaman dalam melaksanakan suatu pekerjaan. Dalam penelitian ini faktor lingkungan kerja mengukur sejauh mana hubungan para pekerja dengan pekerja lainnya serta para pekerja dengan atasan mereka atau mandor.

Hubungan sosialisasi dalam bekerja merupakan salah satu faktor kenyamanan dalam melaksanakan setiap pekerjaan, oleh karena itu kenyamanan dalam bekerja tentunya berpengaruh terhadap lingkungan kerja baik. Pekerja yang merasa nyaman bekerja akan memberikan kemampuan terbaiknya dalam bekerja dan begitupun sebaliknya pekerja yang tidak merasakan kenyamanan dalam lingkungan kerjanya akan bekerja dengan tidak mampu memaksimalkan kemampuan kerjanya.

- Upah Kerja

Upah kerja atau kompensasi merupakan suatu balas jasa atas apa yang telah dikerjakan oleh para pekerja. Tentunya kompensasi atau upah dalam pekerjaan bekisting berpengaruh terhadap kinerja para pekerja. Namun perlu diketahui juga dalam peningkatan kinerja upah bukan merupakan satu-satunya faktor yang berpengaruh terhadap peningkatan kinerja khususnya dalam suatu proyek konstruksi. Dengan kompensisi yang sesuai maka para pekerja akan merasa dihargai dan hal itu akan memberikan dampak bagi mereka untuk bekerja dengan baik dan memiliki tanggung jawab atas pekerjaan tersebut.

- Disiplin Kerja

Disiplin kerja merupakan sikap yang ditunjukkan para pekerja dalam mematuhi dan menaati peraturan-peraturan yang diberlakukan dalam lingkup pekerjaan khususnya dalam pelaksanaan pekerjaan bekisting semi modern pada konstruksi bangunan gedung. Dalam suatu pekerjaan pekerja yang memiliki disiplin yang baik mampu meningkatkan efesiensi waktu 
kerja semaksimal mungkin dengan cara menghindari pemborosan waktu kerja serta menaati peraturan perusahaan yang berdampak pada keamanan pekerja dalam melaksanakan pekerjaan bekisting pada proyek konstruksi gedung. Faktor disiplin kerja dirasa memberikan pengaruh terhadap peningkatan kinerja dalam melaksanakan pekerjaan dalam pekerjaan proyek konstruksi maupun pekerjaan yang lainnya.

\section{KESIMPULAN DAN SARAN}

\section{Kesimpulan}

Berdasarkan hasil analisa dan pembahasan, maka dapat ditarik kesimpulan penelitian adalah sebagai berikut :

- Berdasarkan hasil analisa yang dilakukan, maka didapatkan faktor-faktor yang mempengaruhi kinerja sumber daya manusia dalam pelaksanaan pekerjaan bekisting semi modern pada konstruksi bangunan gedung yaitu meliputi faktor kemampuan kerja, faktor disiplin kerja, faktor upah kerja, faktor lingkungan kerja dan faktor pengawasan kerja.

- Dari hasil analisa regresi linear berganda terhadap para pekerja diperoleh faktor yang paling dominan adalah faktor kemampuan kerja, dengan nilai koefisien B terbesar yaitu 0,291, diikuti oleh faktor pengawasan kerja $(0,211)$, faktor lingkungan kerja $(0,131)$, faktor upah kerja (123), dan faktor disiplin kerja $(0,087)$.

- Berdasarkan hasil analisa metode AHP, Menurut Pakar Ahli faktor-faktor yang mempengaruhi kinerja pekerjaan bekisting semi modern dominan dipengaruhi oleh faktor kemampuan kerja. Hasil urutan faktor-faktor yang mempengaruhi kinerja meliputi kemampuan kerja $(0,245)$, pengawasan kerja (0,238), lingkungan kerja $(0,220)$, disiplin kerja $(0,155)$ dan upah kerja $(0,141)$. Hasil analisa metode AHP menguatkan hasil analisa regresi linear berganda dikarenakan hasil kedua metode tersebut menghasilkan faktor kemampuan kerja sebagai faktor yang dominan. dikemukakan saran yang menjadi rekomendasi yaitu sebagai berikut :

- Berdasarkan hasil penelitian, faktor kemampuan kinerja merupakan faktor yang dominan mempengaruhi kinerja pekerjaan bekisting semi modern pada konstruksi bangunan gedung, oleh karena itu untuk bisa memaksimalkan kinerja sumber daya manusia dalam hal kemampuan kerja, perusahaan dirasa perlu melakukan program pelatihan kerja yang bisa berupa pelatihan tentang metode pelaksanaan kerja yang dirasa akan mampu memaksimalkan kemampuan pekerja di dalam melaksanakan pekerjaan. Selain itu juga perlu adanya evaluasi kepemimpinan para mandor melihat pengaruh gaya kepemimpinan mandor dalam mengawasi pekerjaan bekisting memiliki peranan yang penting.

- Bagi peneliti berikutnya, pengembangan dari penelitian ini bisa dilanjutkan dengan analisis sistem rekrutmen pekerja bekisting semi modern. Dengan sistem perekrutan yang tepat dirasa mampu memaksimalkan kinerja sumber daya manusia dalam pekerjaan proyek sehingga pengembangan penelitian dalam hal tersebut dirasa perlu dilakukan.

\section{DAFTAR PUSTAKA}

Asiyanto. 2010. Formwork For Concrete. Jakarta : UI-Press.

F.Wigbout, Ing. 1987 Bekisting (Kotak Cetak). Jakarta : Erlangga.

Robert L. Mathis \& John H. Jackson. 2006.

Human Resources Management,

Edisi sepuluh : Penerbit Salemba Empat.

Saaty, T.L. 1990. The Analytic Hierarchy Process. New York : McGraw Hill.

Sutrisno, Edi. 2009. Manajemen Sumber Daya Manusia. Jakarta : Kencana Prenada Media Grup.

Wigbout, Ing. 1997. Buku Pedoman Tentang Bekisting. Jakarta : Penerbit Erlangga.

\section{Saran \\ Dari hasil analisa dan kesimpulan, maka dalam penelitian ini dapat}

